\title{
Physical activity and depression among Health and Social Science students at Public Sector University, Dammam, KSA
}

\author{
Mubashir Zafar ${ }^{1,2}$, Yaseen Almabrouk², Mohammed Al Qurain², Jaffer Marzooq² \\ ${ }^{1}$ Family and Community Medicine department, College of Medicine, University of Hail, Saudi Arabia \\ ${ }^{2}$ College of Public Health, Imam Abdurrahman Bin Faisal University, Saudi Arabia
}

\begin{abstract}
Background. Lack of physical activity and depression are the common problem among university students. The purpose of this study was to compare the physical activity and depression between health science students and social science students at Public Sector University, Dammam, KSA.

Methods. It's a cross sectional study and participant were selected by using multistage cluster sampling. International physical activity questionnaire (IPAQ) and "Becks depression scales were used to determine the physical activity and depression. Students of age group between 20 and 25 years were included. Comparison of depression and physical activity between health and social students was determined through chi square and Man Whitney $U$ test. $\mathrm{P}$ value $<0.05$ was considered significant.

Results. The mean age of participants was $21.09 \pm 1.49$ years. Among health and social science students, $41.3 \%$ and $25.9 \%$ were suffering from severe depression respectively $(p<0.05)$. Mean and SD of mild physical activity among health and social science students were $150.96 \pm 147.89$ and $171.13 \pm 160.63$ respectively with $p$ value is 0.04 . Mean and SD of moderate physical activity among health and social science students were $175.16 \pm 157.07$ and $204.93 \pm 152.57$ respectively with $p$ value is 0.06 . Mean and SD of vigorous physical activity among students of health and social science were $169.65 \pm 148.77$ and $219.28 \pm 146.04$ respectively with $p$ value is 0.05 .

Conclusion. Results of study found that health science students had high prevalence rate of depression and low level of physical activity compare to social sciences students.
\end{abstract}

Keywords: depression, health, physical activity, science, social, students

\section{INTRODUCTION}

There are different factors which restrict the physical activity among students such as inconvenience, academic burden and social obligation (1). Previous study found that health science students have less physical active compare to social science students because of more academic burden and not time for physical activity and behaviors of health science students are more towards study than physical exercise (2). Other study results have found that personal barrier or social factors have reduced the physical activity among health science students (3).
Depression has become inevitable with increasing time; it does not only encompass aged people but also undergraduate students, housewives, employee's etc. in its circle. Many researches have been carried out among medical students and result found that a higher prevalence of depression among medical students and low physical activity than general population. According to different studies, stress among medical students has been ranging from $12 \%$ to $73 \%(4-5)$. There are different factors which restrict the physical activity among students such factors as inconvenience, academic obligations, social obligation (6). 
Different studies result found that depression are common in public sector medical students, in USA the prevalence of depression is $15.2 \%$ (5), $21.7 \%$ in Malaysia (4), 29.1\% in India (6), and Private medical school students the prevalence as $19 \%$ in USA (7), $49.1 \%$ in India (8), and $60 \%$ in Pakistan (9).

According to different studies result found that nearly half of the students were found to be depressed with $2 \%$ having severe depression $(10,11)$. Depression was found to be present in $60 \%$ and $70 \%$ in two different studies of medical and private colleges. The studies also show that there was no difference of gender with regard to the development of depression symptoms (12-16).

The objective of this study is to compare prevalence of physical activity and depression between health and social science students at public sector university, Dammam, KSA.

\section{METHODS}

\section{Study setting and study design}

Two health science colleges and two social science colleges were selected in the public sector university. Health Science Colleges: College of Medicine and college of applied medical sciences. Social science colleges: College of Business administration and college of commerce. The total strength of students in these colleges is 2,000 (estimated). Out of total, 71 participants were selected from each college. The age of students was approximately between 20 and 25 years. This is the cross-sectional study.

\section{Study tool}

The study instrument was used a validated and structured questionnaire comprising of three sections. Section one determined the socio demographic characteristics and section two related to depression which was assessed by a 21 items questionnaire and section three is related to physical activity which comprise of 7 questions. It was prepared in English language.

The scale was used to assess depression level is Beck's depression scale A self-administered questionnaire (17) was utilized. The questionnaire includes BDI-II test which is a 21 items selfreport, having a four-point scale ranging from
0 (symptoms not present) to 3(extreme symptoms). The test requires approximately 5-10 minutes finishing. Participants with a cut off of 20 and above were considered depressed. Total score of 20-30 points towards mild mood disturbance, 30-40 indicates moderate clinical depression and 40-60 displays severe depression. The BDI test is broadly recognized and has been verified for concurrent, construct and content validity. This scale was formerly designed by Aaron T. Beck In 1961 collating patient's illustration of their symptoms-depressed mood, hopelessness, lack of energy, persistent sadness, poor self-esteem, guilt, perception of failure, self-discontent crying irritability, fatigue insomnia decreased appetite, weight loss social withdrawal suicidal thoughts In 1996 the Beck Depression Inventory (BDI) underwent revision as (BDI-II) enhancing its content validity with the aim of focusing on depression symptoms criteria presented by DSM-IV. Numerous researches concentrating on the psychometric assessment of depression used Beck Depression Inventory (BDI) (13-16). Physical activity of the students was determined by International Physical Activity Questionnaire (IPAQ) (18). The study participants answered questions relate to number of days and the duration of the vigorous $(\mathrm{V})$, moderate $(\mathrm{M})$, walking activity (W), and a combined total physical activity score. All scores were expressed in MET-minutes/ week (www.ipaq.ki.se). The following values has been used for the analysis of IPAQ data: -

All scores were expressed in MET-minutes/ week (www.ipaq.ki.se). The following values has been used for the analysis of IPAQ data:

- Walking MET $=3.3 \mathrm{x}$ walking minutes $\mathrm{x}$ walking days;

- Moderate MET $=4.0 \mathrm{x}$ walking minutes $\mathrm{x}$ walking days;

- Vigorous MET $=8.0 \mathrm{x}$ walking minutes $\mathrm{x}$ walking days;

- Total Physical Activity MET = sum of Walking + Moderate + Vigorous MET minutes/ week scores

\section{Sample technique and sample size}

The study participants was recruited through multistage cluster sampling, first two cluster were selected, one for health science and other social science colleges then each college sample collected through stratified sampling and within each col- 
lege participants were selected through simple random sampling. Total 285 students were included in the study and it was calculated by Epi info software. Proportion of depression and physical activity among students from previous study $(16,19)$, It was estimated by using proportion of physical activity $23 \%$ and depression as $25 \%$ at confidence level $95 \%$ and bound of error $5 \%$.

\section{Data collection procedure}

After the approval of respective college administration, students for each year of respective college was approached, briefs the study objective and self-administered questionnaires was distributed to the students. Participation was voluntary. Each participant was explained individually the contents of the questionnaire and the importance of this study Questionnaire was return back after completing the questionnaire.

\section{Inclusion criteria and exclusion criteria}

The inclusion criterion were Age of the participant (18-26), willing to participate in the study. Exclusion criteria for study participants were the students who already diagnosed and treated for any psychological disorder and family history of psychological disorders will be excluded. All those who didn't give their consent will be also excluded.

\section{Study variables, data analysis and ethical consideration}

The dependent variable are physical activity and depression and the independent variable were age, gender, marital status, father's occupation, ethnicity and the addiction history of the participants. Data were entered and analyzed in SPSS 24. Frequencies, mean, deviation and standard deviation were calculated in quantitative variables and proportions were calculated in qualitative variables. To determine the depression and physical activity difference between health and social science colleges, Chi-square and Mann-Whitney-U test was used. The relationship between dependent and independent variables were determined through Chi Square and Kruskal-Wallis-H test. Study protocol was approved from the ethical committee of IAU (IRB-UGS-2020-03-064). Informed written consent was taken prior to fill the questionnaire from each participant. The participants were assured confidentiality and given option to quit from the study without any further questions and implications.

\section{RESULTS}

Mean age (SD) of study participants was $21.2 \pm 1.49$ years. Most $(70.2 \%)$ of study participants were male, majority $(96.8 \%)$ were single, $78.9 \%$ were never smoked in their life and $65 \%$ were securing good GPA in last semester. Most $(82.5 \%)$ of students fathers were employees of companies [Table 1].

Majority (43.5\%) of students were suffering from mild depression. Among health science students, majority $(41.3 \%)$ were suffering from severe depression and social science students majority $(45.9 \%)$ had mild depression and the difference were statistically significant different. $(\mathrm{p}<0.05)$ [Table 2].

Mean and SD of Mild physical activity among health and social science students were $150.96 \pm 147.89$ and $171.13 \pm 160.63$ respectively with $p$ value is 0.04 . Mean and SD of moderate physical activity among health and social science students were $175.16 \pm 75.07$ and $204.93 \pm 152.57$ respectively with $\mathrm{p}$ value is 0.06 . Mean and SD of vigorous physical activity among students of health and social science were $169.65 \pm 148.77$ and $219.28 \pm 146.04$ respectively with $\mathrm{p}$ value is 0.05 [Table 3].

Male students were more suffering from depression in both colleges compare to female this difference statistically significant. Among different academic year, first year students were suffering from depression compare to other year of students in both colleges. Those students were secured high GPA score suffered more depression compare to low GPA students in both colleges and this difference is statistically significant ( $p$ value $<0.05$ ) [Table 4].

Male students, first year students and low GPA students were less active in both colleges compared to female, other academic year's students and high GPA students respectively. These differences were statistically significant $(p$ value $<0.05$ ) [Table 5]. 
TABLE 1. Socio-demographic characteristics of study participants $(n=285)$

\begin{tabular}{|c|c|c|c|c|c|}
\hline & & $\begin{array}{c}\text { Total study } \\
\text { participants }\end{array}$ & $\begin{array}{c}\text { Health Science } \\
\text { College participants } \\
(n=150)\end{array}$ & $\begin{array}{c}\text { Social Science College } \\
\text { participants } \\
(n=135)\end{array}$ & $\mathrm{p}$-value** \\
\hline Sr. No & Characteristics & Frequency (\%) & Frequency (\%) & Frequency (\%) & \\
\hline 1. & Age (years) (Mean $\pm S D$ ) & $21.02 \pm 1.49$ & $21.02 \pm 1.61$ & $21.01 \pm 1.34$ & 0.350 \\
\hline 2. & Gender & & & & 0.743 \\
\hline & Male & $200(70.2)$ & $104(69.3)$ & $96(71.1)$ & \\
\hline & Female & $85(29.8)$ & $46(30.7)$ & $39(28.9)$ & \\
\hline 3. & Marital status & & & & 0.617 \\
\hline & Single & $276(96.8)$ & $146(97.3)$ & $130(96.3)$ & \\
\hline & Married & $9(3.2)$ & $4(2.7)$ & $5(3.7)$ & \\
\hline 4. & Academic year of study & & & & 0.427 \\
\hline & First year & $138(48.42)$ & $74(49.3)$ & $64(47.4)$ & \\
\hline & Second year & $68(23.90)$ & $35(23.3)$ & $33(24.4)$ & \\
\hline & \begin{tabular}{|l|} 
Third year \\
\end{tabular} & $51(17.9)$ & $23(15.3)$ & $28(20.7)$ & \\
\hline & Fourth year & $28(9.80)$ & $18(12)$ & $10(7.4)$ & \\
\hline 5. & Father occupation & & & & 0.061 \\
\hline & Business & $50(17.55)$ & $51(34)$ & $37(27.4)$ & \\
\hline & Job & $235(82.45)$ & $99(66)$ & $98(72.6)$ & \\
\hline 6. & Smoking & & & & 0.902 \\
\hline & \begin{tabular}{|l|} 
Ever \\
\end{tabular} & $60(21.10)$ & $32(21.3)$ & $28(20.7)$ & \\
\hline & Never & $225(78.9)$ & $118(78.7)$ & $107(79.3)$ & \\
\hline 7. & $\begin{array}{l}\text { Academic score (GPA)* (Last } \\
\text { semester) }\end{array}$ & & & & 0.000 \\
\hline & Low & $34(11.9)$ & $21(14)$ & $3(2.2)$ & \\
\hline & Average & $65(22.8)$ & $48(32)$ & $27(20)$ & \\
\hline & Good & $186(65.3)$ & $81(54)$ & $105(77.8)$ & \\
\hline
\end{tabular}

*low 1-3, average 3-4, good $>4, * *$ Chi-square test

TABLE 2. Prevalence of depression among study participants $(n=285)$

\begin{tabular}{|c|l|c|c|c|c|}
\hline $\begin{array}{l}\text { S. } \\
\text { No }\end{array}$ & Characteristics & $\begin{array}{c}\text { Total study } \\
\text { participants } \\
\text { Frequency n= 285 (\%) }\end{array}$ & $\begin{array}{c}\text { Health Science College } \\
\text { students Frequency } \mathbf{n = 1 5 0} \\
\text { (\%) }\end{array}$ & $\begin{array}{c}\text { Social Science colleges } \\
\text { students Frequency } \\
\mathbf{n}=\mathbf{1 3 5}(\%)\end{array}$ & $*$ P-value \\
\hline 1 & Mild depression* & $124(43.5)$ & $42(28)$ & $59(43.7)$ & 0.04 \\
\hline 2 & $\begin{array}{l}\text { Moderate } \\
\text { depression* }\end{array}$ & $82(28.8)$ & $43(28.66)$ & $39(28.89)$ \\
\hline 3 & Severe depression* & $79(27.7)$ & $65(43.34)$ & $37(27.41)$ & \\
\hline
\end{tabular}

*Beck's depression scale ** chi square test

TABLE 3. Prevalence of physical activity among study participants $(n=285)$

\begin{tabular}{|c|c|c|c|c|c|}
\hline S. No & Characteristics & $\begin{array}{c}\text { Total study } \\
\text { participants Mean } \pm \text { SD }\end{array}$ & $\begin{array}{l}\text { Health Science College } \\
\text { students Mean } \pm S D \\
(n=150)\end{array}$ & $\begin{array}{l}\text { Social Science colleges } \\
\text { students Mean } \pm S D \\
(n=135)\end{array}$ & $* *$ p-value \\
\hline 1 & $\begin{array}{l}\text { Mild physical activity* } \\
\text { (Min/week) }\end{array}$ & $160.47 \pm 150.09$ & $150.96 \pm 147.89$ & $171.13 \pm 160.63$ & 0.04 \\
\hline 2 & $\begin{array}{l}\text { Moderate physical } \\
\text { activity* } \\
\text { (Min/week) }\end{array}$ & $190.88 \pm 170.97$ & $175.16 \pm 157.07$ & $204.93 \pm 152.57$ & 0.06 \\
\hline 3 & $\begin{array}{l}\text { Vigorous physical } \\
\text { activity* } \\
\text { (Min/week) }\end{array}$ & $193.07 \pm 140.76$ & $169.65 \pm 148.77$ & $219.28 \pm 146.04$ & 0.05 \\
\hline 4 & $\begin{array}{l}\text { Total physical activity } \\
\text { (Min/week) }\end{array}$ & $545.89 \pm 145.39$ & $525 \pm 15.67$ & $568 \pm 12.15$ & 0.03 \\
\hline
\end{tabular}

*Inte ysic $s$ * 
TABLE 4. Relationship between socio-demographic characteristics and depression among study participants $(n=285)$

\begin{tabular}{|c|c|c|c|c|c|c|c|c|c|}
\hline & & \multicolumn{4}{|c|}{ Health Science Colleges students } & \multicolumn{4}{|c|}{ Social Science Colleges students } \\
\hline $\begin{array}{l}\text { S. } \\
\text { No }\end{array}$ & Characteristics & $\begin{array}{c}\text { Mild } \\
\text { depression } \\
\text { Frequency (n) } \\
(\%) \\
\end{array}$ & $\begin{array}{c}\text { Moderate } \\
\text { depression } \\
\text { Frequency (n) } \\
(\%)\end{array}$ & $\begin{array}{c}\text { Severe } \\
\text { depression } \\
\text { Frequency } \\
\text { (n) (\%) }\end{array}$ & $* *$ P-value & $\begin{array}{c}\text { Mild } \\
\text { depression } \\
\text { Frequency } \\
\text { (n) (\%) }\end{array}$ & $\begin{array}{c}\text { Moderate } \\
\text { depression } \\
\text { Frequency } \\
\text { (n) (\%) }\end{array}$ & $\begin{array}{c}\text { Severe } \\
\text { depression } \\
\text { Frequency } \\
\text { (n) (\%) }\end{array}$ & **P-value \\
\hline \multirow[t]{3}{*}{1} & Gender & & & & \multirow[t]{3}{*}{0.01} & & & & \multirow[t]{3}{*}{0.04} \\
\hline & Male & $43(77.4)$ & $31(68.2)$ & $30(58.1)$ & & $44(80.6)$ & $27(68.4)$ & $25(57.1)$ & \\
\hline & Female & $19(22.6)$ & $13(31.8)$ & $14(40.9)$ & & $18(19.4)$ & $11(31.6)$ & $10(42.9)$ & \\
\hline \multirow[t]{5}{*}{2} & $\begin{array}{l}\text { Academic year } \\
\text { of study }\end{array}$ & & & & & & & & \\
\hline & First year & $31(50)$ & $22(50)$ & $21(47.7)$ & \multirow[t]{4}{*}{0.02} & $29(46.9)$ & $18(28.1)$ & $17(25)$ & \multirow[t]{4}{*}{0.01} \\
\hline & Second year & $14(22.6)$ & $11(25)$ & $10(22.7)$ & & $15(48.5)$ & $9(18.2)$ & $8(33.3)$ & \\
\hline & Third year & $12(19.4)$ & $3(6.8)$ & $8(18.2)$ & & 13(53.6) & $7(28.6)$ & $7(17.9)$ & \\
\hline & \begin{tabular}{|l|} 
Fourth year \\
\end{tabular} & $5(8.1)$ & $8(18.2)$ & $5(11.4)$ & & $4(10)$ & $5(60)$ & $3(30)$ & \\
\hline \multirow[t]{3}{*}{3} & Smoking & & & & & & & & \multirow[t]{3}{*}{0.05} \\
\hline & Never & $49(80.6)$ & $34(77.3)$ & $35(77.3)$ & \multirow[t]{2}{*}{0.08} & $49(80.6)$ & $30(78.9)$ & $28(77.1)$ & \\
\hline & Ever & 13(19.4) & $10(22.7)$ & $9(22.7)$ & & 13(19.4) & $8(21.1)$ & $7(22.9)$ & \\
\hline \multirow[t]{4}{*}{4} & $\begin{array}{l}\text { Academic } \\
\text { score (GPA)* } \\
\text { (Last semester) }\end{array}$ & & & & & & & & \\
\hline & Low & $6(9.7)$ & $7(18.2)$ & $8(18.2)$ & 0.05 & $1(1.6)$ & $1(2.6)$ & $2(2.9)$ & \multirow[t]{3}{*}{0.07} \\
\hline & Average & $21(35.5)$ & $13(29.5)$ & 14.(29.5) & & $12(22.6)$ & $8(21.1)$ & $6(14.3)$ & \\
\hline & Good & $34(54.8)$ & $24(54.5)$ & $23(52.3)$ & & $48(75.8)$ & $30(76.3)$ & $27(82.9)$ & \\
\hline
\end{tabular}

*low 1-3, average 3-4, good >4, ** Chi-square test

TABLE 5. Relationship between socio-demographic characteristics and physical activity among study participants $(n=285)$

\begin{tabular}{|c|c|c|c|c|c|c|c|c|c|}
\hline \multirow[b]{2}{*}{$\begin{array}{l}\text { S. } \\
\text { No }\end{array}$} & \multirow[b]{2}{*}{$\begin{array}{l}\text { Charac- } \\
\text { teristics }\end{array}$} & \multicolumn{4}{|c|}{ Health Science Colleges Students } & \multicolumn{4}{|c|}{ Social Science Colleges Students } \\
\hline & & $\begin{array}{c}\text { Mild physical } \\
\text { activity } \\
\text { Mean } \pm \text { SD }\end{array}$ & $\begin{array}{c}\text { Moderate } \\
\text { physical activity } \\
\text { Mean } \pm \text { SD }\end{array}$ & $\begin{array}{c}\text { Vigorous } \\
\text { physical } \\
\text { activity } \\
\text { Mean } \pm \text { SD }\end{array}$ & **P-value & \begin{tabular}{|} 
Mild physical \\
activity \\
Mean \pm SD
\end{tabular} & \begin{tabular}{|c|} 
Moderate \\
physical \\
activity \\
Mean \pm SD \\
\end{tabular} & $\begin{array}{c}\text { Severe } \\
\text { physical } \\
\text { activity } \\
\text { Mean } \pm \text { SD }\end{array}$ & $* *$ P-value \\
\hline \multirow[t]{3}{*}{1} & Gender & & & & \multirow[t]{3}{*}{0.06} & & & & \multirow[t]{3}{*}{0.04} \\
\hline & Male & $161.84(155.58)$ & 170.14.5(167.76) & $166.91(146.14)$ & & $162 \pm(153.47)$ & $217.88(119.70)$ & $177(15.02)$ & \\
\hline & Female & $125.97(120.62)$ & $175.65(142.28)$ & 153.04(146.90) & & $169.4(144.37)$ & $187.38(175.37)$ & $149.47(13.01)$ & \\
\hline \multirow[t]{5}{*}{2} & $\begin{array}{l}\text { Academic } \\
\text { year of study }\end{array}$ & & & & & & & & \\
\hline & First year & $152.38(140.06)$ & 172.41(120.79) & $120.23(121.25)$ & \multirow[t]{4}{*}{0.02} & $157.06(13.80)$ & 190.21(13.15) & $133.40(12.89)$ & \multirow[t]{4}{*}{0.01} \\
\hline & Second year & 149.06(122.34) & 214.73(107.71) & $145.50(117.14)$ & & $152.55(14.92)$ & 301.71(13.38) & $154.28(10.39)$ & \\
\hline & Third year & $147.90(123.58)$ & 130.79(104.00) & $224.85(202.35)$ & & $162.55(15.05)$ & $156.52(13.75)$ & $230.95(20.16)$ & \\
\hline & Fourth year & 131.34(121.29) & $175.07(155.16)$ & $243.20(147.09)$ & & $107.98(12.67)$ & 139.11(12.26) & $270.22(15.41)$ & \\
\hline \multirow[t]{3}{*}{3} & Smoking & & & & & & & & \multirow[t]{3}{*}{0.05} \\
\hline & Never & 173.12(155.27) & $177.50(160.45)$ & $122.33(116.54)$ & \multirow[t]{2}{*}{0.08} & 191.42(13.67) & 225.38(20.09) & $148.67(10.04)$ & \\
\hline & Ever & $163.58(152.43)$ & 166.28(158.34) & 207.71(186.29) & & 186.14(17.20) & 129.50(11.21.) & $247.00(15.14)$ & \\
\hline \multirow[t]{4}{*}{4} & $\begin{array}{l}\text { Academic } \\
\text { score } \\
\text { (GPA)* (Last } \\
\text { semester) } \\
\end{array}$ & & & & & & & & \\
\hline & Low & 110(100.8) & $80.00(38.56)$ & $160.00(157.12)$ & 0.05 & $145.98(13.48)$ & 169.52(13.04) & $194.28(18.44)$ & \multirow[t]{3}{*}{0.07} \\
\hline & Average & 198(183.27) & 178.51(159.75) & 193.66(189.31) & & $156.54(14.40)$ & 202.83(12.67) & $253.62(17.35)$ & \\
\hline & Good & 165.92(155.94) & $177.07(162.89)$ & $149.03(139.15)$ & & $148.94(13.18)$ & 215.35(18.31) & $212.07(14.93)$ & \\
\hline
\end{tabular}

*low 1-3, average 3-4, good >4, ** Kruskal-Wallis-H test 


\section{DISCUSSION}

The study results found that health college students had more depression and less physical activity compared to social science students. These differences were statistically significant.

We found out that depression is more common in health science students, mild, moderate and severe $29.3 \%, 29.3 \%$ and $41.3 \%$ respectively as compared to social science students. These results were consistent with the previous studies. In previous studies the depression among the students of public medical students has been estimated to be $15.2 \%$ in USA (21), $24 \%$ in UK (7), $29.1 \%$ in India (8), and $43.8 \%$ in Pakistan (9). Major factors contributed were study burden, less social time, gender, marital status and a past depression history.

In this study, the maximum mean scores of physical activity among social science students compared to health science students. These results are in agreement with the previous studies (20-23) in which the health science students were found lowest score. The low scores may be linked to less time available for leisure activities due to high burden of studies. In this study all level of physical activity among health science students were low compare to social science students and these results are consistent with other studies results $(24,25)$. This results accordance with other studies results $(26,27)$, who found that medical students be less likely to perform physical activity. The results indicated that in spite of awareness, health sciences students scored poorly in stress managing, health and academic liability, and physical activity.

In this study male students in both health and social sciences were more likely to be affected as compared to female. These results were consistent with other study results. Previous study found that males health students are more likely depressed

\section{REFERENCES}

1. Awadalla NJ, Aboelyazed AE, Hassanein MA, Khalil SN, Aftab R, Gaballa II et al. Assessment of physical inactivity and perceived barriers to physical activity among health college students, south-western Saudi Arabia. EMHJ. 2014;20(10):596-604.

2. Bray SR, Born HA. Transition to university and vigorous physical activity: Implications for health and phychological well-being. Journal of American College Health. 2004;52(4):181-188.

3. Craig CL. International Physical Activity Questionnaire: 12-country reliability and validity. Medicine and Science in Sports and Exercise. 2003:35:1381-1395. compared to females students (28). Different reasons are associated with it such as school pressure, peer pressure, family problems, sense of loss, selfdoubt, high expectations etc.

The study results found that students in first academic year were more depressed and more physical active in both health and social science students. These results contradict the previous study results. The previous studies $(29,30)$ found that final academic year students were more depressed and less physical active. The reason to this difference is that availability of resources to the students. One plausible explanation for the results could be the immense study load of health profession students.

The study found that students had smoking habits were more depressed and less physical active. This result was consistent with other previous studies $(31,32)$. The major reason for this situation is that students feel fresh in psychological status and does not intention to go physical activity.

The limitations of study are, first it is the cross sectional study which cannot determine the temporal relationship, second external validity is low due to small sample size.

\section{CONCLUSION}

The study results highlights that health science students were more depressed and less physical active compared to social science students. These finding needs to reform in the health science curriculum which enable students have more physical active and healthy mind.

\section{Acknowledgement}

I should extend my sincere appreciation to the Department of Public Health, Imam Abdulrahman Bin Faisal University for provision of the necessary support that enabled me to fulfill this study.

Conflict of interest: none declared Financial support: none declared

4. Sherina M, Rampal L, Kaneson N. Psychological stress among undergraduate medical students. Medical Journal of Malaysia. 2004;59(2):207-11.

5. Firth-Cozens J. Stress in medical undergraduates and house officers. British Journal of Hospital Medicine. 1989;41(2):161-4.

6. Yusoff M, Rahim AA, Yaacob M. Depression among final year medical students in universiti sains malaysia (USM): associated, risk and determinant factors. European Psychiatry. 2011;26:706.

7. Dahlin ME, Runeson B. Burnout and psychiatric morbidity among medical students entering clinical training: a three year prospective 
questionnaire and interview-based study. BMC Medical Education. 2007;7(1):6.

8. Sidana S, Kishore J, Ghosh V, Gulati D, Jiloha R, Anand T. Prevalence of depression in students of a medical college in New Delhi: A cross-sectional study. The Australasian Medical Journal. 2012;5(5):247.

9. Jadoon NA, Yaqoob R, Raza A, Shehzad MA, Zeshan SC. Anxiety and depression among medical students: a cross-sectional study. Journal of the Pakistan Medical Association. 2010;(60):699-702.

10. Singh A, Lal A, Singh S. Prevalence of depression among medical students of a private medical college in India. Online Journal of Health and Allied Sciences. 2011;9(4):1-4.

11. Inam S, Saqib A, Alam E. Prevalence of anxiety and depression among medical students of private university. Journal of Pakistan Medical Association. 2003:53(2):44-7.

12. Bayram N, Bilgel N. The prevalence and socio-demographic correlations of depression, anxiety and stress among a group of university students. Social Psychiatry and Psychiatric Epidemiology. 2008;43(8):667-72.

13. Guthrie E, Campbell M, Black D, Creed F, Bagalkote H, Shaw C. Psychological stress and burnout in medical students: a five-year prospective longitudinal study. Journal of the Royal Society of Medicine. 1998;91(5):237-43.

14. Rosal MC, Ockene IS, Ockene JK, Barrett SV, Ma Y, Hebert JR. A longitudinal study of students' depression at one medical school. Academic Medicine. 1997;72(6):542-6.

15. Guthrie E, Black D, Shaw C, Hamilton J, Creed F, Tomenson B. Embarking upon a medical career: psychological morbidity in first year medical students. Medical Education. 1995;29(5):337-41.

16. Stewart SM, Betson C, Lam T, Marshall I, Lee P, Wong C. Predicting stress in first year medical students: a longitudinal study. Medical Education. 1997;31(3):163-8.

17. Teri $L$. The use of the Beck Depression Inventory with adolescents. Journal of Abnormal Child Psychology. 1982;10(2):277-84.

18. Craig CL, Marshall AL, Sjostrom M, Bauman AE, Booth ML, Ainsworth BE et al. International Physical Activity Questionnaire: 12-country reliability and validity. Med Sci Sports Exerc. 2003; 35:1381-1395.

19. Al-Qahtani M. Assessing healthy lifestyles in female university students: Eastern province, Saudi Arabia. Saudi J Health Sci. 2017;6:169-175.
20. Wei CN, Harada K, Ueda K et al. Assessment of health promoting lifestyle profile in Japanese university students. Environ Health Prev Med. 2012;17:222e227.

21. Geok SK, Yusof A, Lam SK et al. Physical activity and health promoting lifestyle of student nurses in Malaysia. J Biosci Med. 2015;3:78-87.

22. Bakouei F, Seyedi-Andi SJ, Bakhtiari A et al. Health promotion behaviors and its predictors among the college students in Iran. Int Q Community Health Educ. 2018;38:251-258.

23. Martinez-Lemos RI et al. Perceived Barriers to Physical Activity and Related Factors in Spanish University Students. Open Journal of Preventive Medicine. 2014;4:164-174.

24. Massiera B, Petracovschi S, Jessica C. Ideological challenges to developing leisure sport in Romania: a cultural and historical analysis of the impact of elite sport on popular sport practice. Loisir et Societe/Society and Leisure. 2013;36(1):111-126.

25. Medina C, Barquera S, Janssen I. Validity and reliability of the International Physical Activity Questionnaire among adults in Mexico. Rev Panam Salud Publica. 2013;34(1):21-8.

26. Nasui B, Popescu C. The assessment of the physical activity of Romanian university students. Palestrica of the third millennium Civilization and Sport. 2014;15(2):107-111.

27. Sigmundova D, Chmelik F, Sigmund E, Feltlova D, Fromel K. Physical activity in the lifestyle of Czech university students: Meeting health recommendations. European Journal of Sport Science 2013; 13(6):744-750.

28. Tjia J, Givens JL, Shea JA. Factors associated with under treatment of medical student depression. Journal of American College Health. 2005;53(5):219-24.

29. Ross CE, Mirowsky J. Components of depressed mood in married men and women the center for epidemiologic studies'depression scale. American Journal of Epidemiology. 1984;119(6):997-1004.

30. Karney BR, Bradbury TN. The longitudinal course of marital quality and stability: A review of theory, methods, and research. Psychological Bulletin. 2005;118(1):3.

31. Kwan MY, Cairney J, Faulkner GE, Pullenavegum EE. Physical activity and other health-risk behaviours during the transition into adulthood: A longitudinal cohort study. American Journal of Preventive Medicine. 2011;42(1):14-20.

32. El-Gylany AH, Badawi K, El-Khawaga G, Awadalla N. Physical activity profile of students in Mansoura University, Egypt, Eastern Mediterranean Health Journal. 2011;17(8):694-702. 